Historic, archived document

Do not assume content reflects current scientific knowledge, policies, or practices. 

TECHNICAL PAPER 155 JULY 1958

1.9622 C3T222
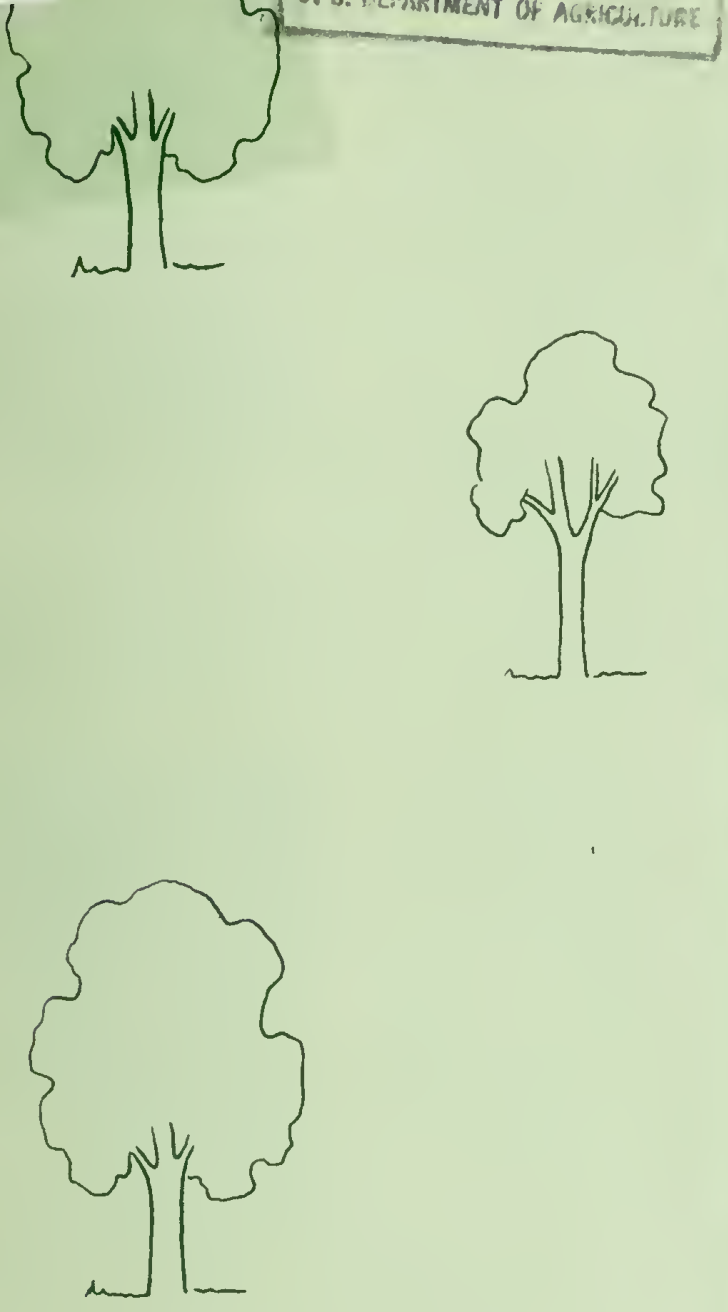

Fardevoods

Upland

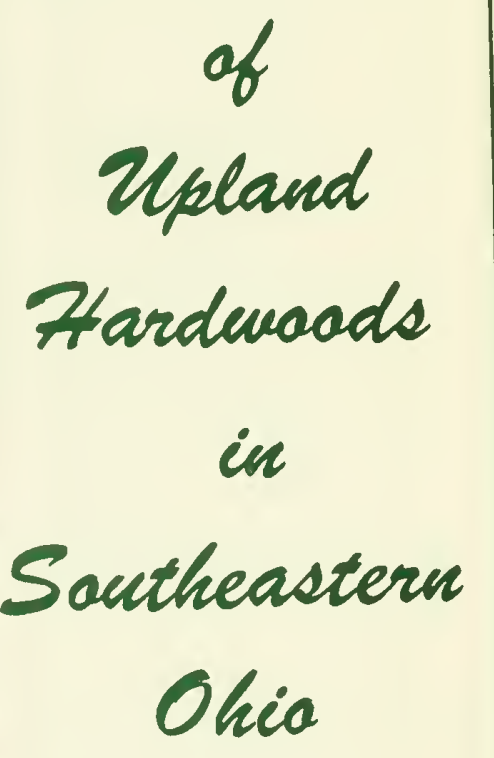

Repraduction

Robert W. Merz

Stephen G. Boyce
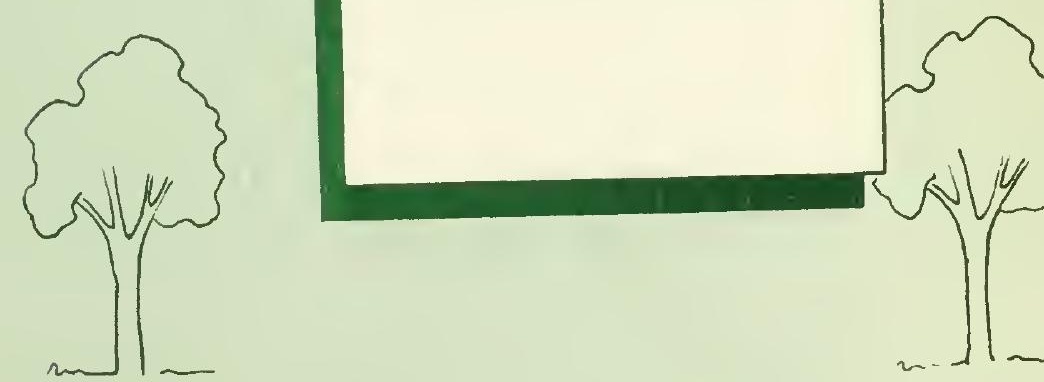

U. S. DEPARTMENT OF AGRICULTURE - FOREST SERVICE CENTRAL STATES FOREST EXPERIMENT STATION - W. G. MCGINNIES, DIRECTOR 


\author{
This report is from the \\ Division of Forest Management \\ CENTRAL STATES FOREST EXPERIMENT STATION \\ Arthur G. Chapman, Chief
Athens (Ohio) Forest Research Center
(Maintained in cooperation with
Ohio University, Athens, Ohio) \\ Benjamin A. Roach, Research Center Leader
}

Central States Forest Experiment Station, U. S. Dept. of Agriculture

Forest Service, 111 Old Federal Building, Columbus 15, Ohio

W. G. McGinnies, Director 


\section{THE AUTHORS}

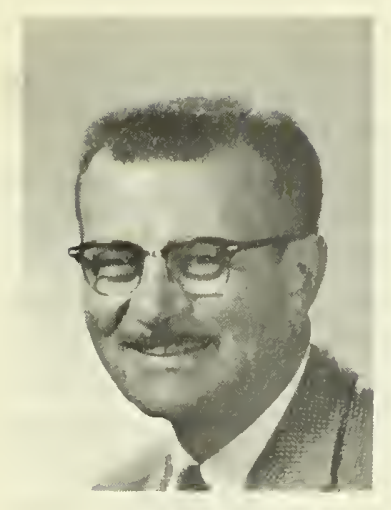

ROBERT W. MERZ is a 20-year man with the Forest Service. He started out in 1935 on the Superior National Forest as a Technical Foreman in the CCC program. Later he served as Ranger on the same forest. In 1945 Bob joined the staff of the Central states station and was assigned to spoil-bank research in Kansas and Ohio. Four years later he became Research Center Leader at Athens, Ohio, and in 1956 was transferred to his present position in charge of the Carbondale Forest Research Center in Illinois. Merz earned both a bachelor and a master degree while majoring in forestry at the University of Minnesota. He is author or co-author of 16 publications, chiefly in the fields of silvics, planting, and spoil-bank reclamation.

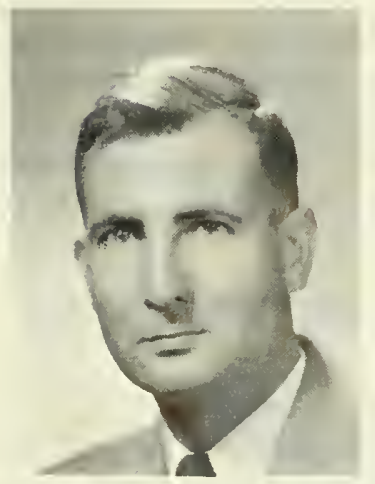

DR. STEPHEN G. BOYCE is a newcomer to the station. In 1954 he began working part time at the Athens Research Center in southeastern Ohio. In 1957 he became a full-time staff member and was transferred to the Carbondale Center as project leader in regeneration and genetics. Steve got his training at North Carolina State College where he earned bachelor and master degrees in forestry and a doctorate in plant ecology. Before coming to the station, he taught biology and botany at Meredith College, North Carolina State College, and Ohio University. Boyce has authored or co-authored 14 technical and scientific publications.

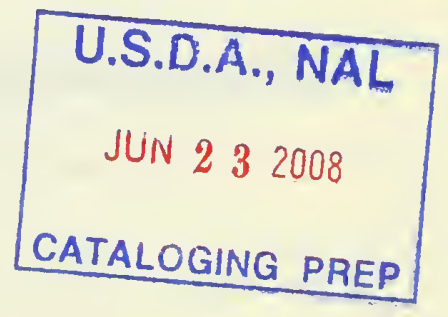




\section{CONTENTS}

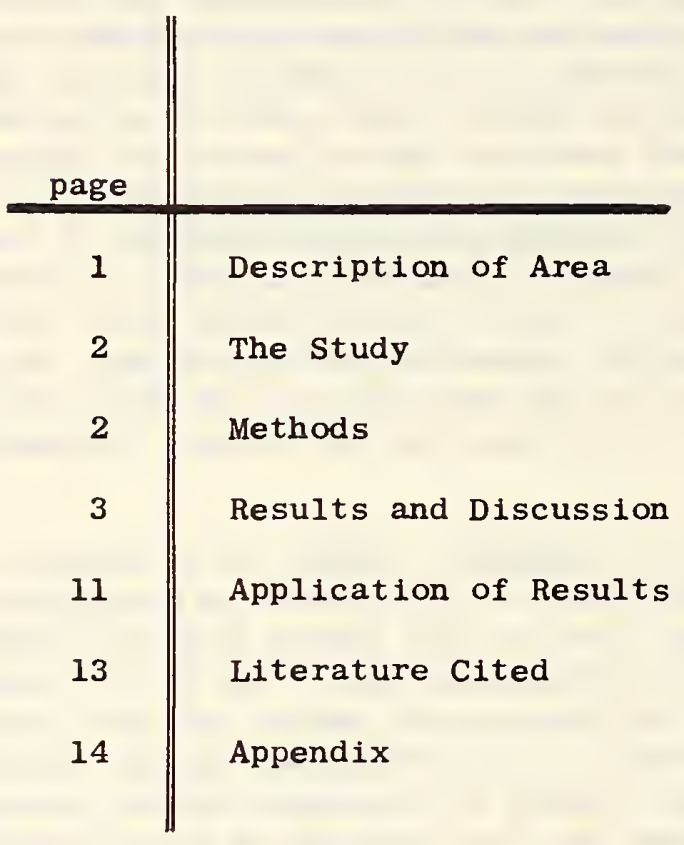


A study of the reproduction in some cut-over areas in southeastern Ohio showed that the number and distribution of some hardwood species were affected by the degree of cutting and the composition of the original stand. However, topography and aspect did not affect the number and distribution of most species on the areas studied.

Cuttings in hardwood stands usually result in the establishment of both wanted and unwanted species. It is often possible to modify cutting practices to favor the establishment of certain species if seed sources are available. This observational study was made to find the species, number, and distribution of reproduction that were associated with the three degrees of cutting.

\section{DESCRIPTION OF AREA}

The Vint on Furnace Experimental Forest is second 'growth and developed following extensive charcoal-wood cuttings made 90 or more years ago. The overstory is essentially even-aged and is of both sprout and seedling origin. Whitel/; chestnut, and black oaks, and shagbark, bitternut, and pignut hickories are most abundant with yellow-poplar, scarlet oak, post oak, northern red oak, red maple, sassafras, dogwood, and sourwood as associates. A few blackgum, bigtooth aspen, black cherry, American elm, and white ash also occur.

\section{Reproduction}

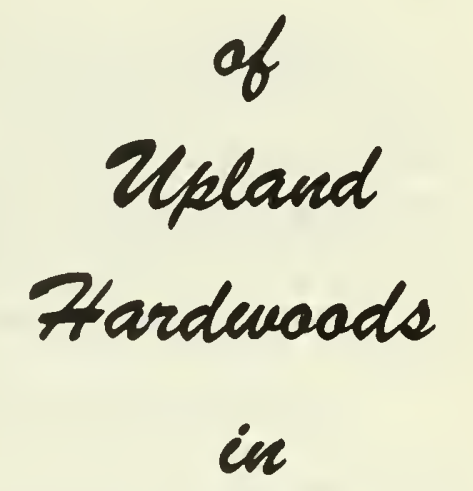

\section{Southeastern}

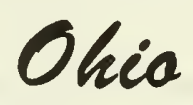

\section{Robert W. Merz}

Stephen G. Boyce

1] Common names of trees according to Little (2). 
The best sites are found on the lower slopes and in the coves, and north-facing slopes usually are better sites than south-facing slopes. Narrow ridges are commonly the least productive sites. In the study area the relief between ridges and coves is approximately 100 feet.

\section{THE STUDY}

Three 5-acre blocks were selected for study. On one block all trees taller than 4.5 feet had been cut; on another block, twothirds of the basal area had been removed by cutting all trees having a merchantable 8-foot sawlog with a 10-inch or larger top; and, on the other block, one-third of the basal area had been removed by a selective cut (table 1). 2 on the heavily cut block, 92 percent of the trees larger than 12 inches $d . b . h$. were cut while on the lightly cut block only 37 percent of trees this size were cut (table 2).

Each block was isolated from adjoining blocks by a 1-chain strip treated in the same way as the block. The partial cuttings were made in the summer and early fall of 1953; the clear cut was made during the winter, spring, and early summer of 1953-54.

\section{METHODS}

Reproduction studies were made in July 1955. Each block was divided into fifty 1-chain-square plots. Two randomly located milacre quadrats were examined in each of the 50 plots. Thus, a total of 100 quadrats were examined in each 5-acre block. Methods for sampling each quadrat and the statistical significance of differences observed are given in the Appendix.

Investigation revealed that only 12 percent of the oaks in the reproduction class originated after cutting. An additional 11 percent had tops that would lead a casual observer to believe they originated since the cut was made, but these oaks had roots that ranged in age from 3 to 27 years (4).

Thus, the data indicate the frequencies and densities of oak reproduction present at the time the plots were examined and do not imply this reproduction necessarily became established as a result of the cutting treatments. This was probably also true for the hickories, maples, beech, elm, and ash. However, 99.9 percent of the yellow-poplar reproduction reported here were seedlings that became established after the cuttings.

2) All tables appear in the Appendix beginning on page 14. 


\section{RESULTS AND DISCUSSION}

\section{Reproduction after Clear Cutting}

The total reproduction was most uniformily distributed on the area that was clear cut (fig. 1). Yellow-poplar reproduction was more abundant in the clear-cut block than in the partially cut blocks (table 3 ). In the clear-cut block there were 6,340 yellowpoplars per acre and they occurred in 87 percent of the quadrats (table 4). Furthermore, 55 percent of all reproduction found was yellow-poplar (table 5). All species of oak reproduction totaled 2,960 stems per acre with one or more oaks in 79 percent of the quadrats. Oaks constituted 25 percent of the total reproduction but made up 67 percent of the original stand. Reproduction of "other" species-incluciing hickories, red maple, sugar maple, black cherry, beech, black locust, bigtooth aspen, American elm, white ash, and black-gum--numbered 2,270 per acre and constituted 20 percent of the total.

This block contained an abumdance of yellow-poplar seedlings despite the fact that this species was a relatively minor constituent in the stands prior to cutting (table 5). These results, however, are consistent with observations made by McCarthy (3) who states that under certain conditions good yellow-poplar reproduction often follows clear cutting of old-growth stands containing some seed trees.

Figure 1.--Reproduction on north-facing slope of clear-cut plot.

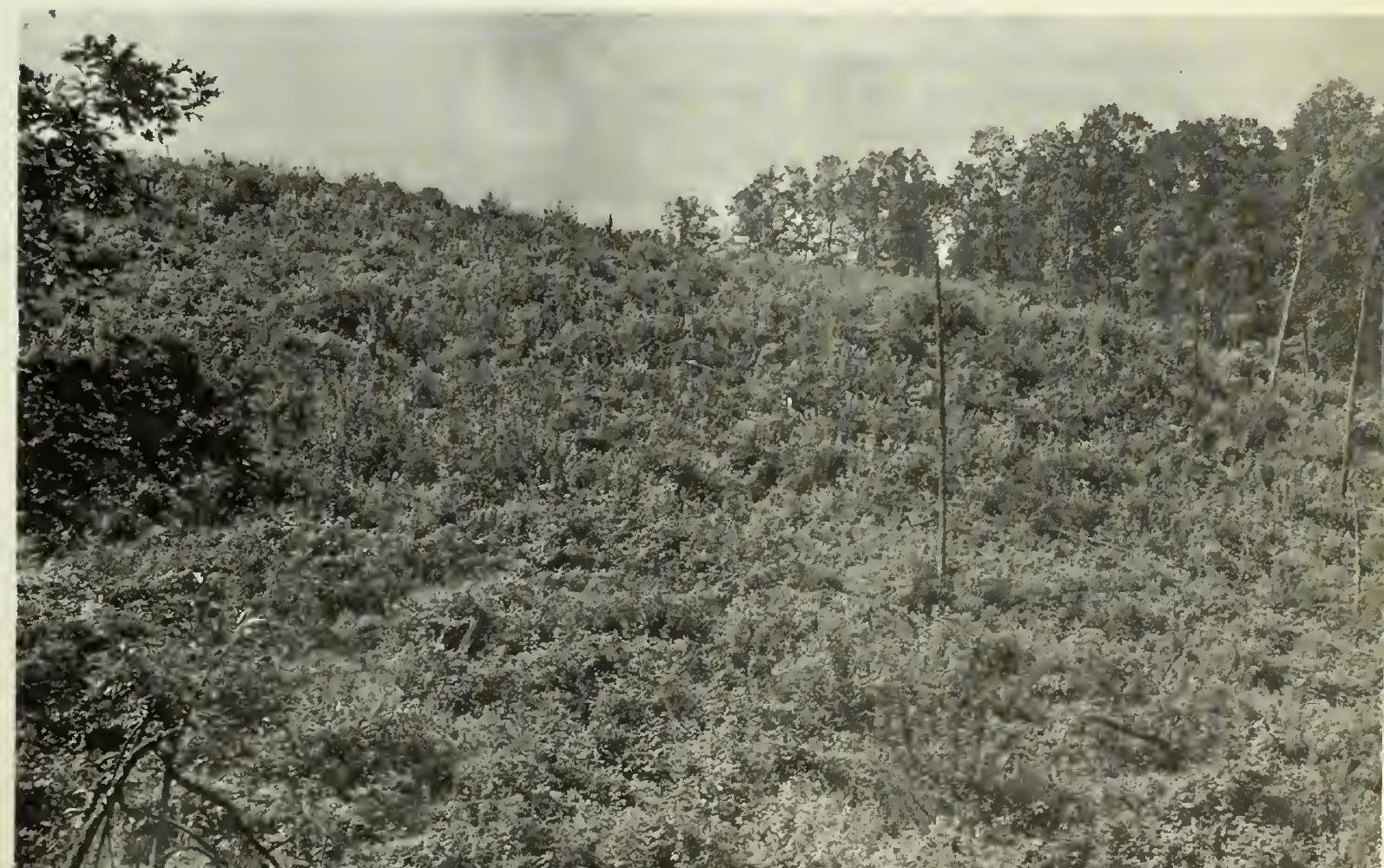


Tree seedlings, shrubs, herbs, vines, and obstructions covered about 88 percent of the clear-cut block (table 6) which was greater than in the partially cut stands. Nearly half the area was covered with herbaceous plants and vines which was at least 60 percent greater than in the partially cut blocks (figs. 2 and 3 ). Grape was an important competing plant at the time the study was made. Patches of grape often formed dense shade and overtopped many seedlings and sprouts (fig. 4). However, there were more than 9,000 oaks and yellow-poplars per acre which seems sufficient to insure a well-stocked stand even though large numbers may be lost through competition.

The cover of oaks in the clear-cut block was about $1 / 4$ of that in the partially cut blocks and the cover of yellow-poplar was very low in 211 blocks. The cover of these species was not related to their densities. For example, there were more than 6,000 yellow-poplars per acre in the clear-cut blocks but they covered less than 1 percent of the area.

In the clear-cut block there exists the potential for developing stands of: (1) Principally yellow-poplar; (2) mixed hardwoods consisting of yellow-poplar, oaks, and other species; or (3) principally oaks. It is not known what cultural practices would be needed to assure stands of the above compositions. However, with no further treatment, a mixed hardwood stand consisting mainly of oaks and yellow-poplar will probably result. To obtain a pure stand of yellow-poplar would undoubtedly require several cleaning and release cuttings.

\section{Reproduction after Heavy Cutting}

The heavily cut block had less than half as much yellowpoplar reproduction per acre as the clear-cut plot (table 3). Even so, 60 percent of the quadrats had one or more yellow-poplar seedlings, which made up 31 percent of the total reproduction ( $f i g .5$ ). This was a marked change from the original stand where yellow-poplar made up only 1 percent of the trees (table 5). There was almost twice as much oak reproduction in this block $(5,140$ per acre) as in the clear-cut block and at least one oak was found in 95 percent of the quadrats. The oaks constituted 53 percent of the total tree reproduction, more than twice the percentage they attained in the clear-cut block. Other less important species made up the remaining 16 percent. 
Figure 4 (right).--A dense growth of grapevines on the clear-cut plot.

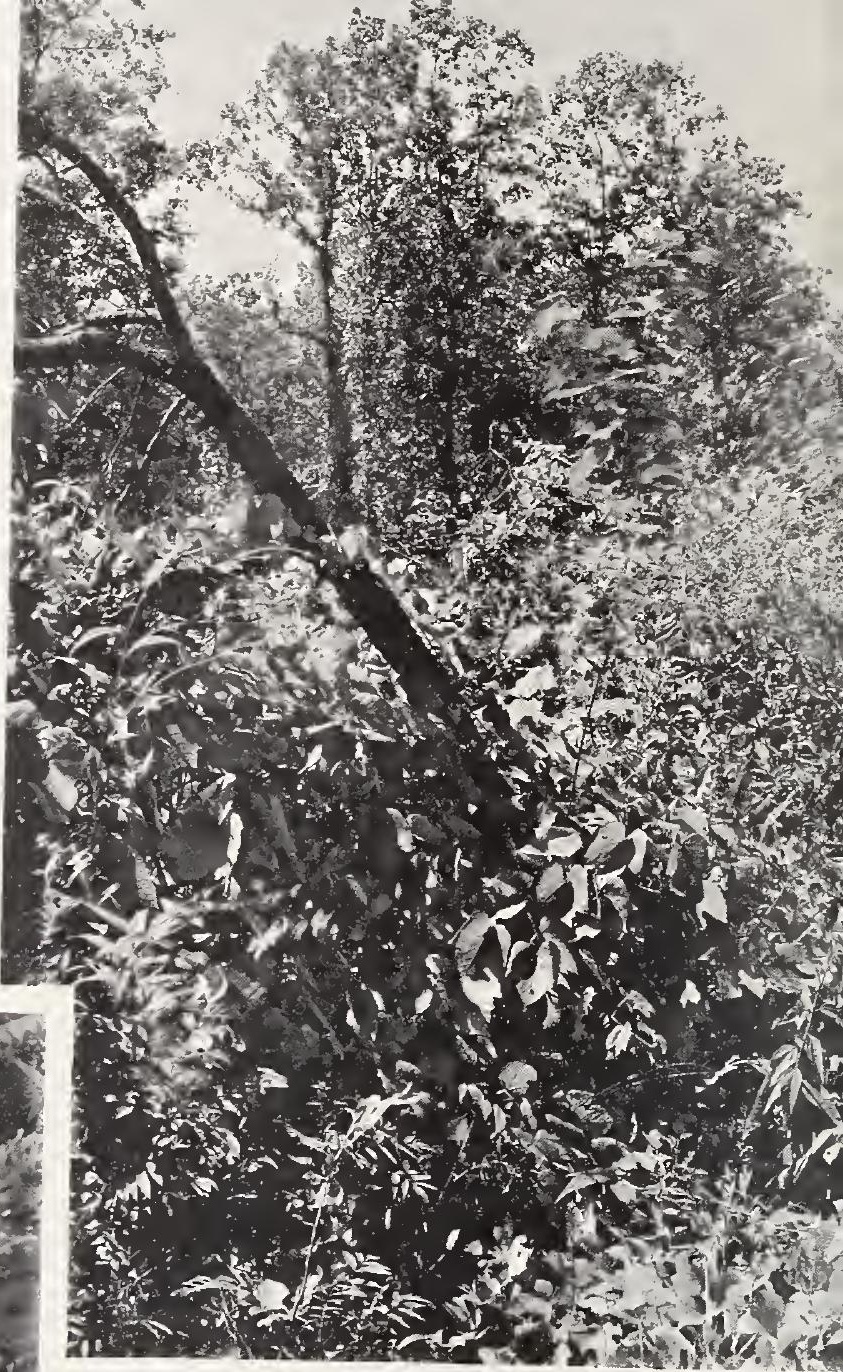

Figure 5 (left).--Yellowpoplar reproduction competing successfully with dense sumac where a heavy cut was made. 
The cover occupied by oaks was four times what it was in the clear-cut block (table 6). Conversely, cover from herbaceous plants, vines, and obstructions was much less than in the clearcut block. The area unoccupied by plants at the time of examination, and classed as "open," was somewhat higher than in the clear-cut block.

After cutting, this block was a mosaic of conditions ranging from areas heavily shaded by remaining overstory trees to openings completely void of an overstory (fig.6). Because the trees were selected for cutting on the basis of merchantability and size, the heaviest cuts were made on the best sites where the trees were largest. As a result the lower and middle north slopes, where most of the trees were large enough to be merchantable, were virtually clear cut. On the balance of the block the cutting was more selective and individual or small groups of trees were cut that created openings of various sizes. The heaviest residual stand was on the ridge where many of the trees were smaller than sawlog size. Residual chestnut oaks were numerous on the ridge, and the few residual yellow-poplars were located on the lower, south-facing slope.

Figure 6.--Heavily cut plot. In foreground is lower north slope that was almost clear cut. Residual stand of chestnut oak on upper slope and ridge may be seen in center of photo.

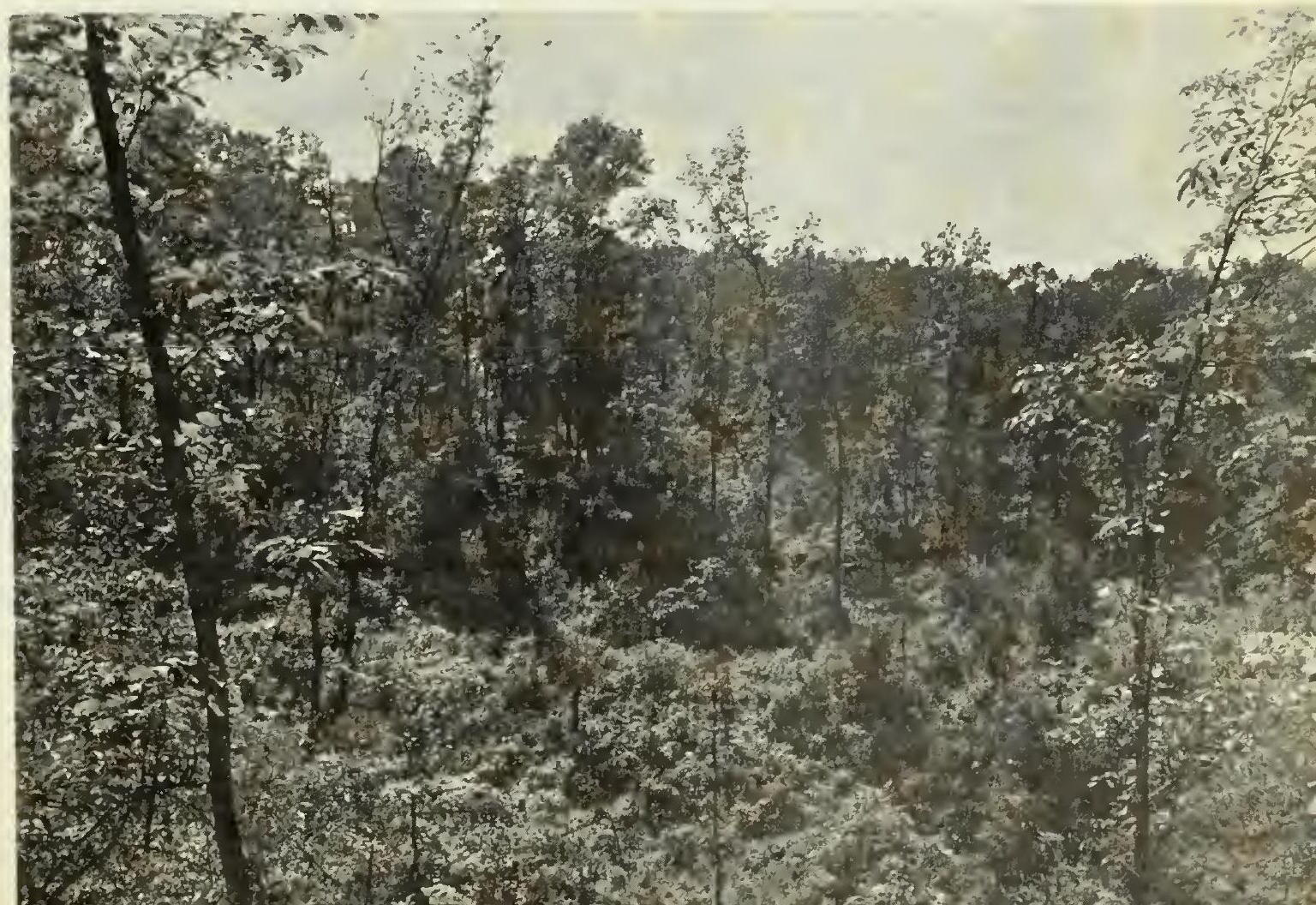


The distribution of yellow-poplar seedlings reflected the mosaic pattern of cutting described above. They were most abundant where conditions approached clear cutting and least abundant where there were no openings. Yellow-poplar became established in the large openings at about the same rate as in the clear-cut block; thus substantiating the evidence that openings of $1 / 4$ acre or larger must be created to favor this species.

In contrast to yellow-poplar in this block, oak reproduction was more abundant where the least cutting was done. Much of the oak reproduction was found in the residual chestnut oak stand on the ridge.

On the basis of the reproduction present when this study was made, it seems possible to convert the lower north-facing slopes to pure yellow-poplar stands. But without cleanings and release cuttings, a stand of oaks and other species, as well as yellow-poplar would result. In the remaining area a mixed hardwood stand would also result, except that yellow-poplar would be very infrequent.

\section{Reproduction after Light Cutting}

The light cutting was more favorable for the oaks than for yellow-poplar. In the lightly cut stand (one-third of the basal area removed) yellow-poplars were found on 47 percent of the quadrats (table 4). There was an average of 1,180 yellow-poplars per acre (table 3) which constituted only 9 percent of the total reproduction (table 5). In contrast, there were 9,310 oak stems per acre and they were found in 96 percent of the quadrats. The oaks constituted 73 percent of all reproduction. Species other than yellow-poplar and oak had a density of 2,290 per acre and occurred on 78 percent of the quadrats.

The "open" area was greater in this block than where the heavier cuts were made (table 6). This was because fewer herbaceous plants and vines developed under the shade of the trees that remained.

The openings resulting from cutting were seldom larger than $1 / 10$ acre and were well distributed as would be expected where several criteria for cutting were used (fig. 7). As in the heavily cut block, more yellow-poplar reproduction was found in openings than under the overstory. Probably the reason there were fewer seedlings of this species and limited distribution was because the openings created by cutting were small. Oak seedlings, however, were present throughout the plot as is evidenced by their high frequency (table 4). 
Figure 7.--Typical conditions within lightly cut plot. Note stump in foreground where tree was cut. Similar opening can be seen in right baclsground.

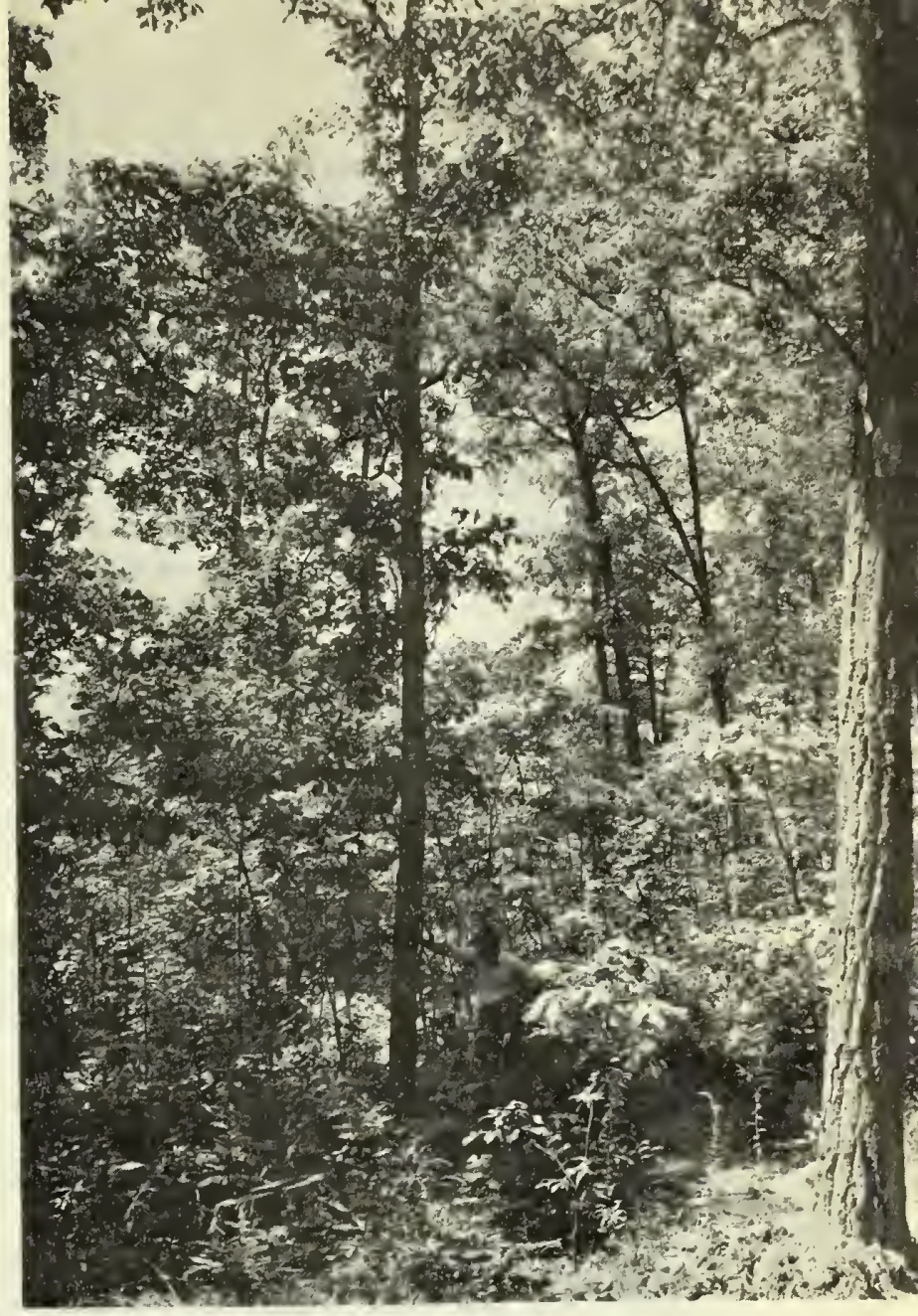

It seems certain that cuttings of this type favor the oaks, and not yellow-poplar.

\section{Effects of Topography on Frequency and Density of Reproduction}

Density of reproduction was unrelated to slope position in the clear-cut block except for yellow-poplar which was more abundant on the lower slope (table 3 ). Where the heavy cut was made, density of yellow-poplar was related to slope position and to degree of cutting to a highly significant degree. Here the stoclsing increased from 750 stems per acre on the ridge site to more than 10 times this amount on the lower slope. On the basis of evidence from the clear-cut block it seems quite obvious that this was a result of the heavier cutting that took place on the lower slopes rather than to direct effects of topography. The density of oak reproduction was also related to slope position and degree of cutting. On lower slopes the density was significantly less than the block averages. 
In the lightly cut block yellow-poplar reproduction was rather uniform in density except for the middle slope where the density was below average. This was probably a chance result and should not be attributed to unique conditions associated with middle slopes as such. Density of oak reproduction was greater on the ridges and less on the lower slopes than on the block as a whole. Since the oak reproduction included many seedling sprouts with old root systems, their distribution was affected by conditions existing before cutting. The high density on the ridge was also due to the large number of chestnut oak seedlings found on the ridge of this block.

Reproduction of "other" species showed significantly greater densities on the middle and lower slopes than on the upper slopes and ridges. Because there were indications of a similar trend in the other two blocks, it was believed that this difference was due more to the location of seed trees of the "other" species than topographic position.

There were no significant differences in frequency of reproduction among topographic positions for the three degrees of cutting (table 4). In the clear-cut block 80 percent or more of every quadrat examined, regardless of slope position, contained at least one yellow-poplar. On the partially cut blocks, yellowpoplars were more frequent on some topographic positions, but these were areas where larger openings occurred.

Regardless of slope position and degree of cutting, at least one oak was found in 64 percent or more of the quadrats. For the partially cut blocks the frequency was not less than 75 percent.

The frequency of species other than yellow-poplar or oaks was not related to slope position and appeared to be independent of the frequency of the yellow-poplar and oaks. When all the species are taken together, there was no slope position among blocks where the frequency of reproduction fell below 98 percent (table 6).

Thus, degree of cutting had more affect on the density and frequency of reproduction among slope positions than topography. Had topography been important, differences in densities and frequencies would have been most apparent in the clear-cut block. 
on the clear-cut and the lightly cut blocks the density and frequency of yellow-poplar were not affected by aspect (tables 7 and 8 ). In contrast on the heavily cut block, the density and frequency of yellow-poplar were much higher on the north-facing slope than on the south-facing slope. However, since cutting was uniformly distributed over the clear-cut and lightly cut blocks and was unequally distributed between the north and south aspects of the heavily cut block, it must be concluded that degree of cutting had a greater affect on the density and frequency of yellow-poplar than aspect.

The density of oak reproduction was (1) lower than expected on the south aspect of the clear-cut block, (2) not different from the average on the heavily cut block, and (3) higher than the average on the south aspect of the lightly cut block. Because the oak reproduction included seedlings, seedling-sprouts, and sprout clumps, this distribution probably resulted from stand conditions existing previous to cutting.

The frequencies of oak were high on both aspects of all blocks. On the clear-cut block the frequency was slightly lower on the south aspect than on the north aspect but was not different between aspects for the other two blocks.

The density of "other" species was higher on the south aspect of the clear-cut block but was not different between aspects for the other two blocks. The frequency of the "other" species was relatively high on both aspects of all blocks indicating uniform occurrence.

\section{APPLICATION OF RESULTS}

This study shows that definite reproduction patterns can be expected after cutting even-aged oak-hickory forests of southeastern Ohio. However, variations can be expected and should be taken into consideration if the composition and basal area of the overstory of a particular stand are greatly different from the stands studied. 


\section{Light Cuts}

When individual trees are selected for cutting and approximately one-third of the basal area is uniformly removed from a stand, oaks can be expected to make up most of the reproduction. Most of these oaks will be individuals established previous to cutting, they will be abundant, and they will be well distributed over the area.

\section{Heavy Cuts}

When all trees having a merchantable 8-foot sawlog with a 10-inch or larger top are cut and when the basal area is reduced by two-thirds, the reproduction can be expected to consist of a mixture of oaks and some yellow-poplar, if seed sources of the latter are present. Since this type of cut normally creates various-sized openings of unequal distribution, the reproduction will not be uniformly distributed. Oaks will be more abundant in and near the smaller openings and yellow-poplar will be more abundant in 1/4-acre-or-larger openings. This type of cut permits the least control over the distribution and abundance of reproduction.

\section{Clear Cuts}

When all trees taller than 4.5 feet are cut, yellow-poplar can be expected to make up most of the reproduction where there are seed sources. The yellow-poplar will be primarily seedlings established after the cutting; they will be very abundant and well distributed over the area.

\section{Species other than Yellow-Poplar and Oaks}

In all three degrees of cutting, hickories, red maple, sugar maple, black cherry, beech, elm, ash, and other tree reproduction can be expected to comprise about 20 percent of the total tree reproduction and to shade about 25 percent of the area. Hawthorne, hazelnut, huckleberry, blueberry, New Jersey tea, and sumac can be expected to shade 2 to 6 percent of the area. Neither clear cutting nor light cutting greatly changes the frequency or cover of these species.

After clear cutting, herbaceous plants and vines can be expected to shade 40 to 50 percent of the area. In partially cut stands these plants can be expected to shade 25 to 30 percent of the area. 


\section{Group-Selection Cutting}

The advantages of both selection cutting and clear cutting can be combined by use of the group-selection system. Observations in this study and elsewhere indicate that small openings from $1 / 2$ to 1 acre in size are adequate for the establishment of good reproduction. Furthermore, with the group-selection method of cutting, a source of seed for the openings and growing stock for future cuts are retained. If the openings are made near sources of yellow-poplar seed, a good stocking of this species along with oaks can be expected. In any case, oak reproduction probably will exceed 1,000 stems per acre.

\section{LITERATURE CITED}

(1) Fernald, Merritt Lyndon

1950. Gray's manual of botany. Ed. 8, 1,632 pp., illus. New York.

(2) Little, Elbert L., Jr.

1953. Check list of native and naturalized trees of the United States (including Alaska). U. S. Dept. Agr. Handb. 4l, 472 pp.

(3) McCarthy, E. F.

1933. Yellow-poplar characteristics, growth and management.

U. S. Dept. Agr. Tech. Bul. 356, 57 pp., illus.

(4) Merz, Robert $\%$. and Boyce, Stephen G.

1956. Age of oak "seedlings". Jour. Forestry 54: 774-775, illus. 


\section{APPENDIX}

Methods for Sampling Quadrats

For each quadrat all tree reproduction up to 4.5 feet in height and sprouts that obviously originated after cutting, regardless of height, were recorded by species and number. The distribution of quadrats by slope position and aspect are given in table 9 .

The percent of each quadrat shaded by tree reproduction, shrubs, and herbs and vines was estimated.

The percent of each quadrat occupied by logs, limbs, stumps, and the bases of standing trees when they effectively reduced the area available for plant establishment was estimated. These were designated "obstructions."

The percent of area not occupied by any of the above and considered available for future plant establishment was estimated. This was recorded as "open area" even though these areas may have been shaded by residual overstory.

For each quadrat, these estimates were proportionately adjusted to give a total of 100 percent. The adjustments rarely exceeded 5 percent for any one category. Each plot was classified by north or south aspect and four topographic positions as follows:

Ridge.--The crest of the slope usually delimited by a distinct change in degree of slope,

Upper slope.--The upper one-third of the slope located immediately below the ridge,

Middle slope.--The middle one-third of the slope located immediately below the upper slope, and

Lower slope.--The lower one-third of the slope bounded on the lower side by a drainage channel and usually delimited on the upper side by a distinct change in degree of slope.

\section{The Significance of Differences and Variation in This Study}

The statistical significance of differences in density of reproduction among degrees of cutting for species or groups of species is summarized in table 10. 
Differences in density among blocks are highly significant for yellow-poplar and oaks, meaning that odds are one in 100 that differences are due so chance and not to degree of cutting. For the reproduction of other species the differences in density between the clear-cut and heavily cut blocks and between lightly and heavily cut blocks were also highly significant.

Table 1.--Basal areal/ per acre on the three blocks before and after cutting

\begin{tabular}{llccc}
\hline $\begin{array}{c}\text { Cutting } \\
\text { treatment }\end{array}$ & $:$ & \multicolumn{4}{c}{ Basal area } \\
\cline { 2 - 4 } & Before cutting & After cutting & $:$ & Cut \\
\hline Clear cut & 91 & Square feet & Percent \\
Heavily cut & 86 & - & 100 \\
Lightly cut & 76 & 52 & 32
\end{tabular}

1/ The average total cross-sectional area per acre in square feet of all trees 3.6 inches or larger in diameter at breast height. 
Table 2.--Stand density by species and

\section{diameter before and after cutting}

(Number per acre)

\begin{tabular}{|c|c|c|c|c|c|c|c|}
\hline \multirow{2}{*}{$\begin{array}{l}\text { Species and } \\
\text { diameter } \\
\text { (inches) }\end{array}$} & \multicolumn{3}{|c|}{ Clear cut } & \multicolumn{2}{|c|}{ Heavily cut } & \multicolumn{2}{|c|}{ Lightly cut } \\
\hline & $:$ & Before & : After & : Before & : After & : Before & : After \\
\hline \multicolumn{8}{|l|}{ Yellow-poplar } \\
\hline $4-1,1]$ & & 4.6 & 0 & 1.2 & 1.2 & 5.8 & 5.8 \\
\hline $12+2 /$ & & 2.0 & 0 & 1.0 & .0 & 1.0 & 1.0 \\
\hline \multicolumn{8}{|l|}{ Oaks } \\
\hline $4-11$ & & 40.8 & 0 & 86.0 & 75.8 & 44.4 & 37.2 \\
\hline $12+$ & & 49.4 & 0 & 52.4 & 3.4 & 42.4 & 26.8 \\
\hline \multicolumn{8}{|l|}{ Other species } \\
\hline $4-11$ & & 35.4 & 0 & 8.8 & 7.8 & 19.8 & 19.2 \\
\hline $12+$ & & 1.6 & 0 & 1.4 & .6 & 3.0 & 1.4 \\
\hline \multicolumn{8}{|c|}{ Totals by sizes } \\
\hline $4-11$ & & 80.8 & 0 & 96.0 & 84.8 & 70.0 & 62.2 \\
\hline $12+$ & & 53.0 & 0 & 54.8 & 4.0 & 46.4 & 29.2 \\
\hline Grand Total & & 133.8 & 0 & 150.8 & 88.8 & 116.4 & 91.4 \\
\hline II & & s tre & $\begin{array}{l}\text { from } \\
\text { from }\end{array}$ & 1.6 and & $\begin{array}{l}5 \text { inche } \\
\text { larger i }\end{array}$ & $\begin{array}{l}d \cdot b \cdot h \cdot \\
d \cdot b \cdot h .\end{array}$ & \\
\hline
\end{tabular}


Table 3.--Density of individuals per acre by species and groups of species for topographic positions and degrees of cutting

(Number per acre)

\begin{tabular}{clllll}
\hline Degree & $:$ & & $:$ & $:$ & Average \\
of cutting & $:$ Ridge & $:$ Upper & $:$ Middle $:$ Lower $:$ for all slope \\
and species & $:$ & $:$ slope $:$ slope $:$ slope $:$ positions 1 \\
\hline
\end{tabular}

Clear cut

\begin{tabular}{llllll} 
Yellow-poplar & 6,150 & 5,750 & 5,958 & $7,393 * 2 /$ & 6,340 \\
All oaks & 2,300 & 3,250 & 3,542 & 2,642 & 2,960 \\
"Other" species & 2,250 & 1,857 & 2,666 & 2,357 & 2,270 \\
\cline { 2 - 6 } \multicolumn{1}{c}{ All species } & 10,700 & 10,857 & 12,166 & 12,392 & 11,570
\end{tabular}

Heavily cut

Yellow-poplar

All oaks

"Other" species

All species

\begin{tabular}{cllll}
$750 * *-3 /$ & $1,441 * *$ & $4,500 * *$ & $7,600 * *$ & 3,020 \\
5,900 & 5,853 & 4,639 & $3,000 * *$ & 5,140 \\
$950 *$ & 1,353 & 2,139 & 1,800 & 1,600 \\
\hline $7,600 * *$ & $8,647 *$ & $11,278 * *$ & $12,400 * *$ & 9,760
\end{tabular}

Lightly cut

Yellow-poplar

A11 oaks

"Other" species

All species

\begin{tabular}{rllll}
1,409 & 1,467 & $800 *$ & 1,375 & 1,180 \\
$12,000 * *$ & 9,466 & 9,200 & $1,875 * *$ & 9,310 \\
$1,363 * *$ & $1,600 *$ & $3,050 * *$ & $3,625 * *$ & 2,290 \\
\hline $14,772 * *$ & 12,533 & 13,050 & $6,875 * *$ & 12,780
\end{tabular}

1/ If slope position did not affect number of individuals found, the average number per acre should not differ from the average for all slope positions.

2/ *Significant differences between expected and actual number of individuals per acre. Odds are 19 against 1 that differences are due to chance rather than slope position.

$3 / * *$ Highly significant differences between expected and actual number of individuals per acre. Odds are 99 against 1 that differences are due to chance rather than slope position. 
Table 4.--Frequency of reproduction by species and groups of species for topographic positions and degrees of cutting

\section{(In percent)}

\begin{tabular}{|c|c|c|c|c|c|c|}
\hline $\begin{array}{l}\text { Degree of cutting } \\
\text { and species and } \\
\text { species groups }\end{array}$ & $\begin{array}{ll}: & \\
: & \text { Ridge } \\
\end{array}$ & $\begin{array}{ll}: & \text { Upper } \\
: & \text { slope } \\
\end{array}$ & $\begin{array}{l}: \\
\vdots \\
:\end{array}$ & $\begin{array}{l}\text { Middle } \\
\text { slope }\end{array}$ & $\begin{array}{ll}: & \text { Lower } \\
: & \text { slope } \\
\end{array}$ & $\begin{array}{c}\text { All } \\
: \text { positions } \\
\end{array}$ \\
\hline \multicolumn{7}{|l|}{ Clear cut } \\
\hline \multicolumn{7}{|l|}{ At least one: } \\
\hline Yellow-poplar & 80 & 86 & & 92 & 89 & 87 \\
\hline Oak & 70 & 82 & & 100 & 64 & 79 \\
\hline "Other" & 85 & 61 & & 83 & 85 & 78 \\
\hline Any species & 100 & 100 & & 100 & 100 & 100 \\
\hline \multicolumn{7}{|l|}{ Heavily cut } \\
\hline \multicolumn{7}{|l|}{ At least one: } \\
\hline Yellow-poplar & 40 & 62 & & 69 & 60 & 60 \\
\hline Oak & 90 & 94 & & 97 & 100 & 95 \\
\hline "Other" & 60 & 70 & & 75 & 60 & 70 \\
\hline Any species & 90 & 100 & & 100 & 100 & 98 \\
\hline \multicolumn{7}{|l|}{ Lightly cut } \\
\hline \multicolumn{7}{|l|}{ At least one: } \\
\hline Yellow-poplar & 41 & 53 & & 40 & 75 & 47 \\
\hline Oak & 95 & 97 & & 100 & 75 & 96 \\
\hline "Other" & 64 & 73 & & 87 & 88 & 78 \\
\hline Any species & 100 & 100 & & 100 & 88 & 99 \\
\hline
\end{tabular}


Table 5.--Compositionl/ of the original stands and the reproduction for the three degrees of cutting

(In percent)

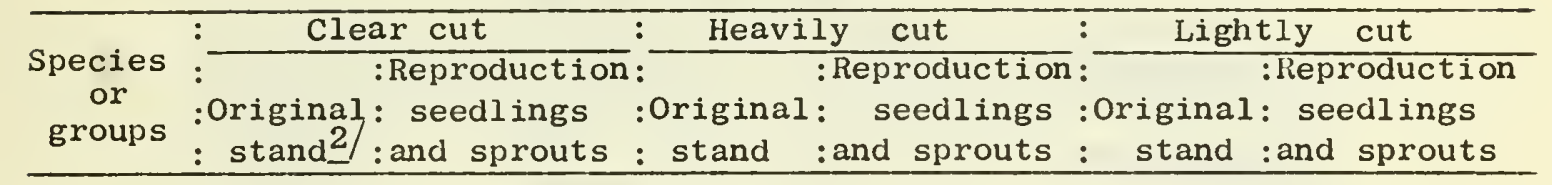

Yellow-

poplar

55

1

31

6

9

Al1

oaks

67

25

92

53

74

73

Other

species

28

20

7

16

20

18

Total

100

100

100

100

100

100

Total

stems per

acre

$133.8 \quad 11,570$

150.8

9,760

$115.2 \quad 12,780$

1/ Based on numbers of trees or seedlings, seedling sprouts, and sprout clumps.

2/ Includes all trees 3.6 inches d.b.h. and larger. 
Table 6.--Percent of cover for plants, obstructions, and open area for three degrees of cutting

(In percent)

\begin{tabular}{|c|c|c|c|}
\hline Species & : Clear cut & : Heavily cut & : Lightly cut \\
\hline or category & $:$ & Cover & \\
\hline Yellow-poplar & 0.6 & 1.6 & 0.7 \\
\hline Oaks & 3.4 & 13.9 & 13.0 \\
\hline "other",trees & 24.4 & 25.1 & 25.3 \\
\hline Shrubs 1 / & 2.0 & 6.4 & 5.6 \\
\hline Herbs and vines 2 & 48.4 & 29.8 & 26.3 \\
\hline Obstructions & 9.1 & 5.6 & 6.4 \\
\hline Open & 12.1 & 17.6 & 22.7 \\
\hline Total & 100.0 & 100.0 & 100.0 \\
\hline
\end{tabular}


Table 7.--Density of individuals per acre by species and groups of species for north and south aspects

and degree of cutting

(Number per acre)

\begin{tabular}{llll}
\hline Degree & $:$ & $:$ & Average \\
of cutting & $:$ North aspect & $:$ South aspect & $:$ for all \\
and species & $:$ & $:$ & $:$ aspects \\
\hline
\end{tabular}

\section{clear cut}

Yellow-poplar

All oaks

"Other" species

All species

\begin{tabular}{lll}
6,156 & 6,666 & 6,340 \\
$3,500 * 1 /$ & $2,000 * * 2 /$ & 2,960 \\
$1,844 *$ & $3,028 * *$ & 2,270 \\
\hline 11,500 & 11,694 & 11,570
\end{tabular}

Heavily cut

Yellow-poplar

All oaks

"Other" species

All species

\begin{tabular}{cll}
$4,717 * *$ & $1,574 * *$ & 3,020 \\
5,217 & 5,074 & 5,140 \\
1,652 & 1,555 & 1,600 \\
\hline $11,586 * *$ & $8,203 * *$ & 9,760
\end{tabular}

Lightly cut

Yellow-poplar

All oaks

"Other" species

All species

\begin{tabular}{lcl}
1,109 & 1,240 & 1,180 \\
$7,739 * *$ & $10,648 * *$ & 9,310 \\
2,391 & 2,204 & 2,290 \\
\hline $11,239 * *$ & $14,092 * *$ & 12,780
\end{tabular}

1/ *Significant differences between expected and actual number of individuals per acre. Odds are 19 against 1 that differences are due to chance rather than slope position. 2/ **Highly significant differences between expected and actual number of individuals per acre. Odds are 99 against 1 that differences are due to chance rather than slope position. 
Table 8.--Frequency of reproduction by species and groups of species for aspects and degrees of cutting

(In percent)

\begin{tabular}{|c|c|c|c|c|c|c|}
\hline \multirow{3}{*}{$\begin{array}{l}\text { Degree of cutting } \\
\text { and species and } \\
\text { species groups }\end{array}$} & \multicolumn{6}{|c|}{ Aspect } \\
\hline & : & North- & : & South- & $:$ & Both \\
\hline & : & facing & : & facing & $\therefore$ & aspects \\
\hline
\end{tabular}

Clear cut

At least one:

Yellow-poplar

All oaks

89

83

87

"Other" species

Any species I/

83

72

79

72

89

78

100

100

100

Heavily cut

At least one:

Yellow-poplar

All oaks

"Other" species

93

$31 * * 2 /$

60

98

92

95

Any species

74

67

70

100

96

98

$\underline{\text { Lightly cut }}$

At least one:

Yellow-poplar

All oaks

"Other" species

43

50

47

93

98

96

Any species

72

83

78

98

100

99

I/ *Significant differences between expected and

actual number of individuals per acre. Odds are 19

against 1 that differences are due to chance rather than slope position.

2/ **Highly significant differences between expected and actual number of individuals per acre. Odds are 99 against 1 that differences are due to chance rather than slope position. 
Table 9.--Distribution of quadrats by slope position and aspect for the three degrees of cutting

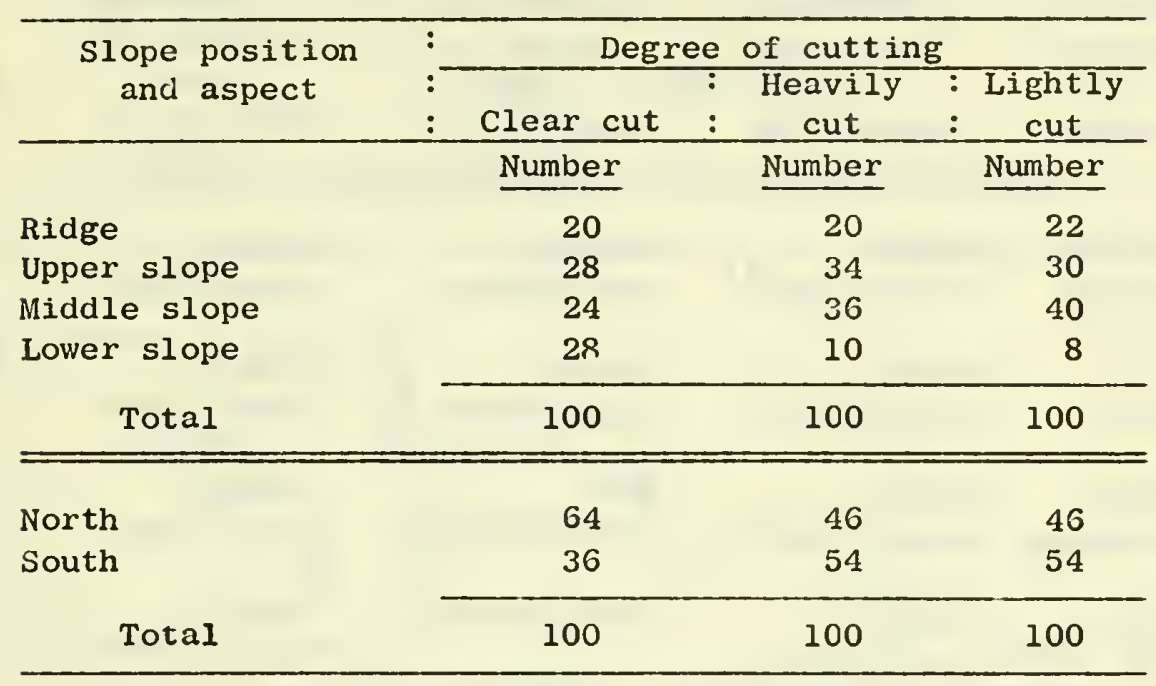


Table 10.--Significance of difference in average density of reproduction between degrees of cutting

\begin{tabular}{cccccc}
\hline & $:$ & Between & Between & $:$ & Between \\
Species & clear cut & clear cut & $:$ & lightly cut \\
or & and & $:$ & and & $:$ & and \\
group & heavily cut & lightly cut & heavily cut \\
& $:$ & blocks & blocks & $:$ & blocks \\
\hline
\end{tabular}

\begin{tabular}{|c|c|c|c|}
\hline $\begin{array}{l}\text { Yellow- } \\
\text { poplar }\end{array}$ & $\begin{array}{l}\text { Highly } \\
\text { significantl/ }\end{array}$ & $\begin{array}{l}\text { Highly } \\
\text { significant }\end{array}$ & $\begin{array}{l}\text { Highly } \\
\text { significant }\end{array}$ \\
\hline $\begin{array}{l}\text { All } \\
\text { oaks }\end{array}$ & $\begin{array}{l}\text { Highly } \\
\text { significant }\end{array}$ & $\begin{array}{l}\text { Highly } \\
\text { significant }\end{array}$ & $\begin{array}{l}\text { Highly } \\
\text { significant }\end{array}$ \\
\hline $\begin{array}{l}\text { Other } \\
\text { species }\end{array}$ & $\begin{array}{l}\text { Highly } \\
\text { significant }\end{array}$ & $\begin{array}{l}\text { Non- } \\
\text { significant2/ }\end{array}$ & $\begin{array}{l}\text { Highly } \\
\text { significant }\end{array}$ \\
\hline Total & $\begin{array}{l}\text { Highly } \\
\text { significant }\end{array}$ & Significantㅍ/ & $\begin{array}{l}\text { Highly } \\
\text { significant }\end{array}$ \\
\hline
\end{tabular}

1/ The probabilities are at least 100 against 1 that differences are due to chance.

2/ The probabilities are less than 20 against 1 that differences are due to chance.

differences are due to chance. 
TERRITORY SERVED BY THE

CENTRAL STATES FOREST EXPERIMENT STATION FOREST SERVICE

U. S. DEPARTMENT OF AGRICULTURE

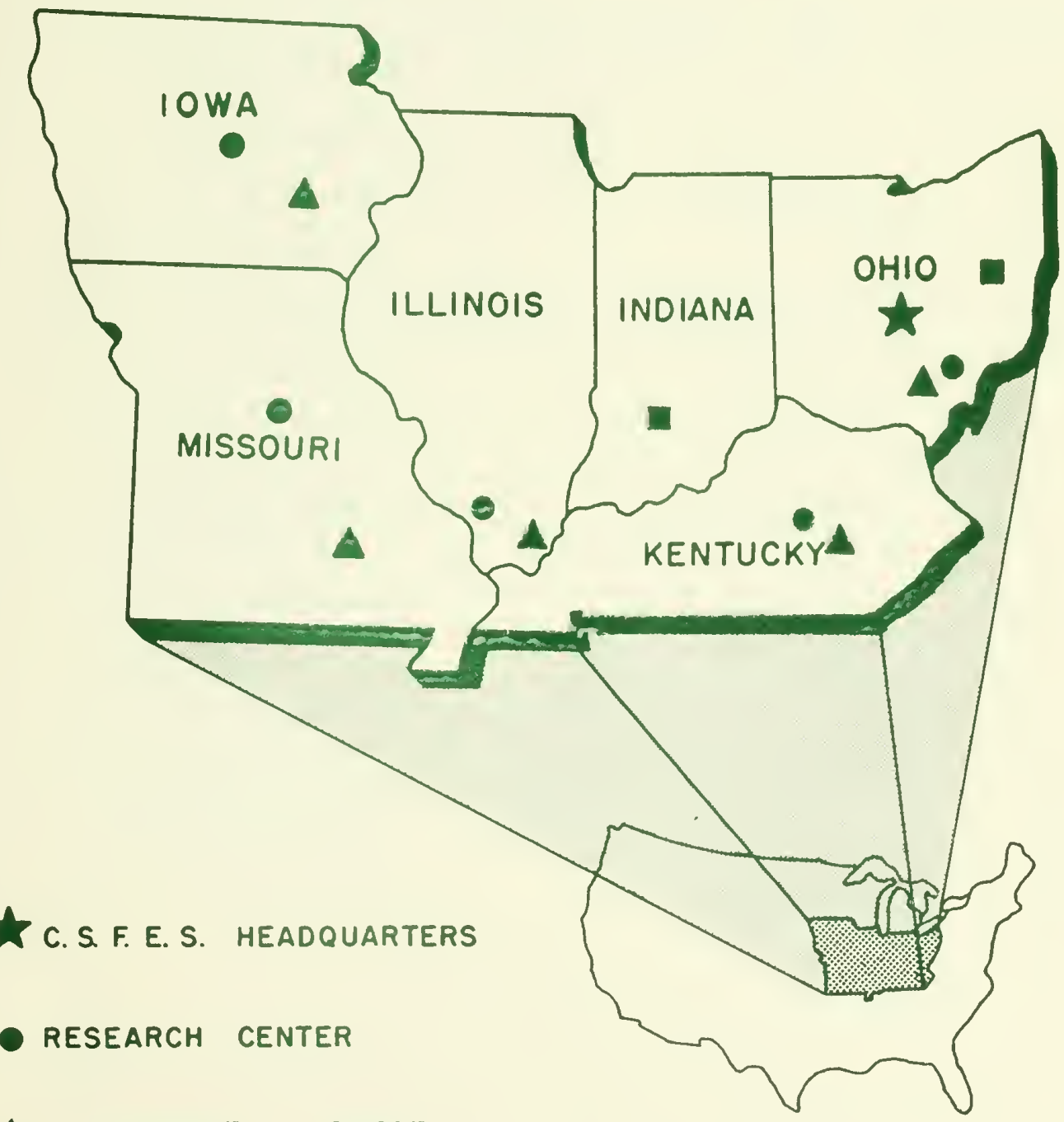

A EXPERIMENTAL FOREST

- BRANCH OFFICE 


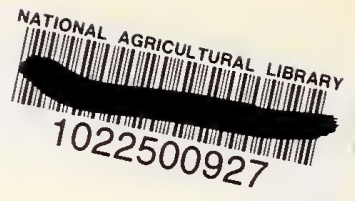

